\title{
Impacts of different drains on the seawater quality of El-Mex bay (Alexandria, Egypt)
}

\author{
Mohamed A. Shreadah ${ }^{1}$, Mamdouh S. Masoud ${ }^{2}$, Abdel-Rhman M. Khattab $^{3}$ and \\ Gehan M. El Zokm ${ }^{1 *}$ \\ ${ }^{1}$ National Institute of Oceanography and Fisheries, Kayet-Bay, Al-Anfoushy, Alexandria, Egypt.
${ }^{2}$ Department of Chemistry, Faculty of Science, Alexandria University, Alexandria, Egypt.
${ }^{3}$ Department of Botany and Microbiology, Faculty of Science, Al-Azhar University, Cairo, Egypt.
}

Received 25 July, 2014; Accepted 25 August, 2014

\begin{abstract}
EI Mex Bay area received domestic, industrial and agricultural waste water from the surrounding area. The need to pay much attention to the potential effects of anthropogenic inputs upon the hydrochemical characteristics of the bay is an emergency. Several water samples have been analyzed for physico-chemical characteristics during 2010/2011: Seven samples from EI Mex bay and 4 samples from drains. The study revealed that $\mathrm{pH}$, salinity, dissolved oxygen, oxidizable organic matter, biological oxygen demand, and chlorophylls-a,b.c, were in the ranges 7.16-8.97; 0.3-42.04; ND-22.26 mg/L; 0.4-112.00 mg O 2 /L; 3.23$111.29 \mathrm{mg} / \mathrm{L} ; 0.11-241.91 \mu \mathrm{g} / \mathrm{L} ; 0.03-242.78 \mu \mathrm{g} / \mathrm{L}$ and $0.01-239.55 \mu \mathrm{g} / \mathrm{L}$, respectively. The increasing organic supply introduced into the studied restricted area characterized by its relative slow rate of selfpurification results in elevation of OOM compared to previous studies. The ranges of nutrients $(\mu \mathrm{M} / \mathrm{L})$

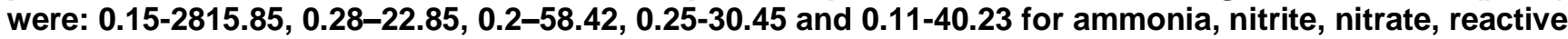
phosphate and reactive silicate, respectively. Principle Component Analysis (PCA) which was used to develop water quality index (WQI) revealed that El-Dekhila Head and EI Qalaa drain were the most polluted sampling sites that resulted from the disposal of industrial, agricultural and domestic wastes. Depending on DIN/DIP ratio of seawater for EI-Mex Bay and adjacent drains the majority of the investigated area sums to be P-limited.
\end{abstract}

Key words: Seawater quality,El-Mex bay, drains, Alexandria, Egypt, nutrient salts, hydrographic characteristics.

\section{INTRODUCTION}

The strategic action plan for Mediterranean (EEAA, 2009) has identified several "hot spots and sensitive areas" on the northern coast of Egypt, which for several decades have been experiencing a continuous increase in population, development and environmental degradation (Shreadah et al., 2006, 2011; Shobier et al., 2011; Shadia et al., 2012;
Abdel Ghani et al., 2013). El-Mex Bay which is located west of Alexandria City is an industrial zone. It receives huge amounts of untreated industrial wastes as a consequence of growing heavy industries (petrochemicals, pulp metal planting, industrial dyes, and textiles) and the uncontrolled disposal of the resulting wastewater transports

\section{${ }^{*}$ Corresponding author. E-mail: gehanelzokm@yahoo.com. Tel +20-3-4801174. Fax +20-3-4801553.}

Author(s) agree that this article remain permanently open access under the terms of the Creative Commons Attribution License 4.0 $\underline{\text { International License }}$ 


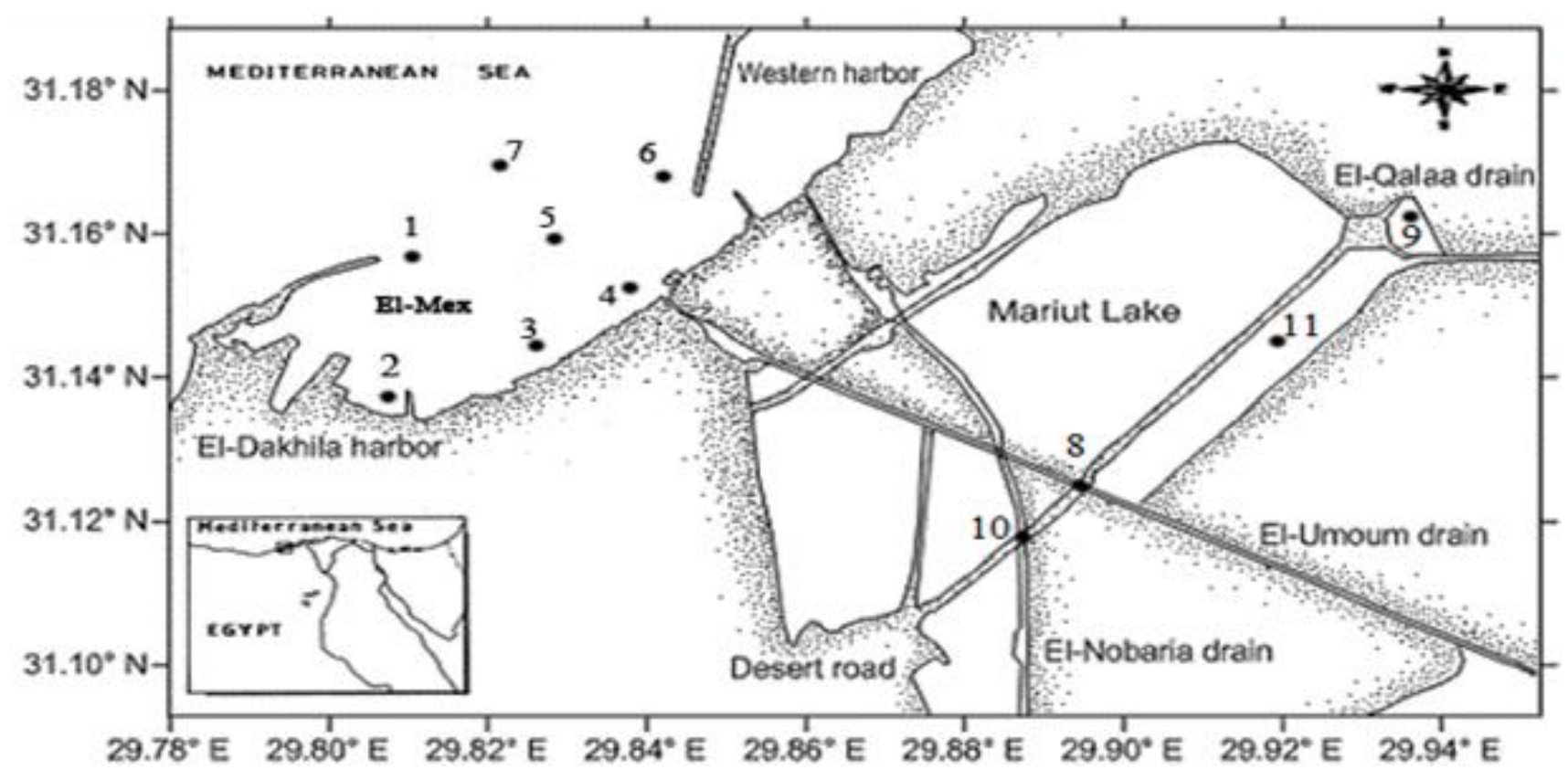

Figure 1. El-Mex Bay area, sampling locations.

the agricultural water from El-Beheira Governorate as well as mixed wastes from the Lake Mariut and discharges them into El-Mex Bay via El Mex pumping station in southern part of the bay. It receives a heavy load of wastewater $\left(2.4 \times 10^{9} \mathrm{~m}^{3} /\right.$ year $)$ both directly to the sea from industrial outfalls and indirectly from Lake Mariut via El-Mex pumping station (Shriadah and Emara, 1992a, b; Emara et al., 1992; Said et al., 1994). The physico-chemical characteristics of El-Mex area have been studied by many authors (Shriadah and Emara, 1996; Emara et al., 1992; Said et al., 1994; Tayel et al., 1996; Mahmoud et al., 2005; Shreadah et al., 2006a, b; Zakaria et al., 2007; Abdallah, 2008; Nassim et al. 2010; El Zokm et al., 2012; Fathy et al., 2012; Okbah et al., 2013; Hamdy et al., 2014). Degradation of water quality due to land-based pollution is a serious problem in the Mediterranean coastal areas. The countries of the Mediterranean Sea basin face a variety of shared environmental problems that are trans-boundary in nature (EEAA, 2009). Two millions cubic meter of partially untreated sewage wastes (treatment efficiency less than $30 \%$ ) are directly disposed to El Umoum drain before the pumping station. El Nubaria sailing cannel is a fresh water cannel of Nile water tells $30 \mathrm{~km}$ south of Alexandria where many new industries dispose their water in this cannel and lead to its pollution before combined with the main basin of Lake Mariut. Two openings off El Mex Bay at El Umoum drain are far with 1.92 and 1.82 $\mathrm{km}$ from El Mex Bay. Principal component analysis is successfully applied to sort out hydrographical and chemical from commonly collected water quality data to establish spatial and temporal variations in water quality
(Olobaniyi and Owoyemi, 2006).

The present study aimed to follow the changes of physicochemical characteristics and study impacts of nutrients salts come from uncontrolled land-based discharge (industrial, agricultural and domestic to El Mex Bay to assess water quality.

\section{Study area}

El-Mex bay is one of the main fishing grounds of Alexandria located between longitude $29^{\circ} 47.1^{\prime}$ to $29^{\circ}$ $50.4^{\prime} \mathrm{E}$ and latitude $31^{\circ} 7.5^{\prime}$ to $31^{\circ} 9^{\prime} \mathrm{N}$ (Figure 1). It represent a shallow sheltered Estuary west of Alexandria, extends for about $15 \mathrm{~km}$ between El-Agamy headland to the west to the Western Harbor to the east and from the coast to a depth of about $30 \mathrm{~m}$. The Bay has a mean depth of $10 \mathrm{~m}$. Its surface area is about $19.4 \mathrm{~km}^{2}$ and its volume is $190.3 \times 10^{6} \mathrm{~m}^{3}$ and the rate of waste water added to the basin via El -Umoum drain is $2452.7 \times 10^{6}$ $\mathrm{m}^{3} / \mathrm{y}$ (Shriadah and Emara 1992 a,b; Said et al., 1994,; Fahmey et al., 1997; Shriadah et al., 2006a,b; Shaltout et al., 2008; Fathy et al., 2012). El-Mex Bay is dominated by two types of currents. El Mex Bay is classified as a microtidal estuary (to $30 \mathrm{~cm}$ ) and coastal currents drive water masses eastward at an average velocity of 0.5 knots. The wave height on the inner shelf reaches 1.5-2 $\mathrm{m}$ in winter (Stanley et al., 2006). Seven stations are chosen within the Bay to cover the whole Bay specially area around industrial activities and 4 samples from the drains. 


\section{MATERIALS AND METHODS}

Water temperatures were measured in situ to the nearest $0.1^{\circ} \mathrm{C}$ by using ordinary thermometer, and also transparency was measured in situ using secchi disc. Salinity of samples was determined by measuring the electrical conductivity using an inductive salinometer (Thermo; Orion $150 \mathrm{~A}+$ ). The $\mathrm{pH}$ - value was measured by using bench type (JENWAY, 3410 Electrochemistry Analyzer pH-meter). The method used to determine oxygen and biological oxygen demand is the common Winkler method, modified by Carritt and Carpenter (1966). Determination of oxidizable organic matter was carried out according to the method described by FAO (1975). Chlorophyll-a,b and c were determine using $0.45 \mu \mathrm{m}$ membrane filter according to Strickland and Parsons (1975). Nutrient salts were spectrophotometrically determined using a double beam spectrophotometer (UV VIS-SPEKOL® 1300/1500 single beam), according to the methods mentioned by FAO (1975).

\section{Residence time}

It is calculated according to El-Gindy et al. (1986) as follows:

Residence time $(t)=\frac{V(S i-S o)}{S i \times Q R}$

So is the salinity in surface layer, $\mathrm{Si}$ is the salinity in subsurface layer; V, the volume of the water in the bay; QR is the rate of fresh water added to the basin.

\section{Evaluation of water quality index}

Lohani and Todino (1984) utilized principal components technique to provide a quick analytical method for the water quality index (WQI) proposed as given by the following formula (Davis, 1986):

$W Q I=\sum_{n=1}^{n}\left(\lambda_{n} / \sum \lambda\right) \times P C n$

For PC Assessment model, $\mathrm{n}$ is the number of effective components, $\lambda_{n}$, are the Eigen values of the effective components, $\Sigma \lambda$ sum of the Eigen values and $\mathrm{PCn}$ are the principal component factor scores. For the evaluation of hot spot sites, principal component factor scores and WQI corresponds to more polluted site evaluated. High values of principal component factor scores mean that this site is from hotspots.

\section{RESULTS AND DISCUSSION}

\section{Hydrographical conditions}

\section{Water temperature}

The maximum temperature was attained in autumn reaching $30.9^{\circ} \mathrm{C}$ at $\mathrm{El}-\mathrm{Qalaa}$, while the minimum temperature was about $15.0^{\circ} \mathrm{C}$ in winter at El-Umoum. The seasonal averages preceded also as normal trend as expected; it increased from winter $\left(19.00^{\circ} \mathrm{C}\right)$ through spring $\left(19.53^{\circ} \mathrm{C}\right)$ reaching maximum level during summer $\left(28.50^{\circ} \mathrm{C}\right)$ and decreased slightly again during autumn $\left(27.07^{\circ} \mathrm{C}\right.$ ) (Table $2 \mathrm{a}$ and $\left.2 \mathrm{~b}\right)$. Hamedy et al. (2014), Okbah et al. (2013), Nessim et al. (2010) and Zakaria et al. (2007) recorded temperature ranges compatible to the present study which are 18.1-29.1, 18-31,15.1-29.9 and 14.5 $31.0^{\circ} \mathrm{C}$ in El Mex Bay water. Temperature changes according to many variables such as season, day time, depth, tide, wind, current, water inflow and turbidity (Whaby and Shriadah, 1984).

\section{Salinity}

In the present study, salinity is used as indicator to reflect changes resulting from the mixing of fresh and seawaters. Salinity of El-Mex Bay was mostly affected by the amount of drainage water of El-Umoum drain and the rate of exchange with the adjoining open sea (Shriadah and Emara 1992a, b, Said et al. 1994; Fahmey et al., 1997; Shriadah et al., 2006a, b; Shaltout 2008; Fathy et al., 2012; Okbah et al., 2013). As illustrated in Table 2a and $2 \mathrm{~b}$, the lowest salinity (0.30) was recorded during spring, while autumn represented the highest salinity (7.30) for drains with an average for the 4 seasons of 3.75. Nessim et al. (2010) recorded salinity range 4.676.44 and average value of 5.79 for drains in El Mex area. Salinity is measured in surface and subsurface layers for El- Mex Bay to calculate the residence time in the bay. As shown in Table 1a, salinity increased with increasing depth and the bay is classified into two water masses overlapping each other. Water mass with salinity $>35$ is identified to occupy most of the bay bottom area. Regionally, the average values of salinity, in general, showed noticeable local variations according to the distance of the different sites from the effluents whereas the annual salinity averages increased seawards and started with 1.68 at El-Qalaa drain to 4.53 at El-Umoum drain reaching maximum level at EL-Mex Bay (St.1-7) 30.76. Based on the distribution of surface salinity in the investigated area salinity gradient identification; stations 8, 9, 10 and 11 characterized by Mixed land drainage type $L$ with salinity $<10.0$ in all seasons. For El Mex Bay in spring 2010, three types of water are recorded due to high water circulation and high water current; Diluted sea water (D) with a salinity range from 30.00 to 38.50 station (1) and Mediterranean Sea water (S) of salinity $>38.50$ stations (2-7) beside L type. For autumn 2010, four types are recorded; Mixed water (M) salinity of 10.0 to 30.0 at stations 5 and 6 . D type, were characterized by stations 1, 2, 3, 4 and 7 beside $L$ type. For winter 2011, four types are obtained; $M$ type for stations 1, 2 and 3; D type for stations 4 and 6 and S type for stations 5 and 7 beside $L$ type. For summer 2011, M type at stations 1,2,3,4 and 5, D type were characterized by equations 6 and 7 beside $L$ type. The data recorded in the present study is in accordance with those of Said et al. (1994); Mahmoud et al. (2005); Zakaria et al. (2007) and Okbah et al. (2013). 
Table 1. List of Stations, site code and different sampling locations.

\begin{tabular}{lccc}
\hline Name & Site Code & Latitude & Longitude \\
\hline El-Dekhila Head & 1 & $31^{\circ} 09^{\prime} 16.1^{\prime \prime}$ & $29^{\circ} 48^{\prime} 17.4^{\prime \prime}$ \\
El-Hexane Factory (cooling station) & 2 & $31^{\circ} 08^{\prime} 34.1^{\prime \prime}$ & $29^{\circ} 48^{\prime} 18.2^{\prime \prime}$ \\
Petrochemicals company & 3 & $31^{\circ} 08^{\prime} 17.7^{\prime \prime}$ & $29^{\circ} 48^{\prime} 44.4^{\prime \prime}$ \\
In front of El-Umum Drain & 4 & $31^{\circ} 09^{\prime} 18.3^{\prime \prime}$ & $29^{\circ} 50^{\prime} 20.9^{\prime \prime}$ \\
Far 500 m from station 4 & 5 & $31^{\circ} 09^{\prime} 51^{\prime \prime}$ & $29^{\circ} 47^{\prime} 59^{\prime \prime}$ \\
In front of Western Harbour & 6 & $31^{\circ} 09^{\prime} 53.6^{\prime \prime}$ & $27^{\circ} 50^{\prime} 47.1^{\prime \prime}$ \\
Far 1200 m from Station 4 & 7 & $31^{\circ} 10^{\prime} 58.2^{\prime \prime}$ & $23^{\circ} 50^{\prime} 33.0^{\prime \prime}$ \\
El-Umum Drain (Near Shore) & 8 & $31^{\circ} 09^{\prime} 18.2^{\prime \prime}$ & $29^{\circ} 55^{\prime} 37.7^{\prime \prime}$ \\
El-Qalaa Drain (Near Shore) & 9 & $31^{\circ} 09^{\prime} 2.88^{\prime \prime}$ & $29^{\circ} 55^{\prime} 36.48^{\prime \prime}$ \\
El-Noubaria Drain (Near Shore) & 10 & $31^{\circ} 07^{\prime} 19.2^{\prime \prime}$ & $29^{\circ} 53^{\prime} 52.8^{\prime \prime}$ \\
Marriott Lake (Near Shore) & 11 & $31^{\circ} 07^{\prime} 19.2^{\prime \prime}$ & $29^{\circ} 53^{\prime} 52.8^{\prime \prime}$ \\
\hline
\end{tabular}

\section{Residence time of El Mex Bay}

The residence time of El-Mex Bay water in the present study varied seasonally as following 1.4 day in spring 2010, 5.62 day in Autumn 2010, 5.33 day in winter 2011 and 12.48 day in summer 2011. El Gindy et al. (1986) recorded residence time value of 1.2 day; however Shaltout (2008) recoded residence time that ranged from 8.6 to 13.3 days. This variation may be attributed to physical barriers.

\section{pH-Value}

Hydrogen ion concentration plays an important role in many of the life processes. Living organisms are very dependent on, and sensitive to $\mathrm{pH}$. As shown in Table $2 \mathrm{a}$, during the period of study, maximum readings of $\mathrm{pH}$ values at waste water stations were observed during winter at Marriutt (8.58) while the lowest $\mathrm{pH}$-value of 7.16 was measured during autumn at El-Qalaa. The $\mathrm{pH}$-value of seawater at El-Mex Bay ranged between 8.97 (summer) at station 1 and 7.36 (winter) at station 3. Most of data lies at alkaline side $(>7-<9)$. Slight variations in the $\mathrm{pH}$ values were observed by comparing the present $\mathrm{pH}$ values with those of the previous studies (Mahmoud et al., 2005; Nessim et al., 2010; Fathy et al., 2012; Okbah et al., 2013). This coincided principally with the relative increase or decrease in the quantity and quality of the discharged effluents. The $\mathrm{pH}$ values of the drain waters showed a dependence on the nature of the effluents conveyed from each drain. The lower values may be associated with high organic matter content in the sewage (Whaby and Shreadah, 1984). The pH-level depends on many characteristic parameters including; temperature, alkalinity, dissolved oxygen, organic matter, chlorophylls as well as minor and major constituents. It seems that the relative high $\mathrm{pH}$-value during summer in waste waters could be attributed to the phytoplankton bloom. The highest $\mathrm{pH}$-value observed during summer at El-Mex Bay stations, was accompanied by an increase in dissolved oxygen (Said et al., 1994; Fahmey et al., 1997). The variability of $\mathrm{pH}$ values in the surface water of El Mex Bay was explained to $55 \%$ by DO followed by organic matter (Tayel et al., 1996).

\section{Water transparency}

The transparency values was affected by domestic, agriculture effluents and suspended matter and floating substances (Whaby and Shreadah, 1984). McCave (1989) pointed out that since water clarity determines several factors affecting water ecosystem, the increase in water clarity may help in explaining define response among oligotrophic, mesotrophic, eutrophic and hypertrophic water bodies to nutrient abatement measures. The regional and seasonal variations of secchi depth were fluctuated between $5.00 \mathrm{~cm}$ during winter at El-Qalaa to $100.00 \mathrm{~cm}$ during summer at Mariut Lake for drains. With respect to El-Mex Bay, the minimum transparency of $30.00 \mathrm{~cm}$ was investigated during summer (St.4) while, winter season gave the maximum level of $370.00 \mathrm{~cm}$ (St.7), with an average for the 4 seasons of $119.29 \mathrm{~cm}$. Lowest Secchi values were observed in El-Mex drains during summer 2011, while El-Mex Bay showed a relatively higher Secchi values. This could be attributed to quantity and quality of the discharged water into El-Mex drains that can be related to the presence of greater amount of particulate materials, including phytoplankton and the effect of discharged water (Said et al., 1994, Fahmey et al., 1997, Shriadah et al., 2006a,b, Shaltout, 2008; Fathy et al., 2012). Fathy et al. (2012) reported transparency range of $28-85 \mathrm{~cm}$ for El Ummum and El 
Table 2a. Seasonal variations of hydrographical parameters at El-Mex Bay (2010-2011).

\begin{tabular}{|c|c|c|c|c|c|c|c|c|c|c|c|c|}
\hline \multirow{2}{*}{ Season } & \multirow{2}{*}{ Stations } & \multirow{2}{*}{ Temp. $\left({ }^{\circ} \mathrm{C}\right)$} & \multicolumn{2}{|c|}{ Salinity } & \multirow{2}{*}{$\mathrm{pH}$} & \multirow{2}{*}{ Transp. (cm) } & \multirow{2}{*}{ DO mg/L } & \multirow{2}{*}{ BOD mgL } & \multirow{2}{*}{ OOM mgO/L } & \multirow{2}{*}{\multicolumn{2}{|c|}{$\frac{\text { Chl-b }}{\mu \mathrm{gL}}$}} & \multirow[t]{2}{*}{ Chl-c } \\
\hline & & & Surface & sub & & & & & & & & \\
\hline \multirow{8}{*}{ Spring (2010) } & 1 & 21 & 32.6 & 42.3 & 7.4 & 140 & 9.26 & 20.17 & 34.4 & 4.9 & ND & ND \\
\hline & 2 & 20 & 38.6 & 43 & 8.05 & 150 & 4.95 & 12.41 & 24 & 16.42 & 0.51 & 8.26 \\
\hline & 3 & 19.5 & 39 & 35.9 & 8.25 & 50 & 5.76 & 14.77 & 5.6 & 5.23 & 1.6 & 9.26 \\
\hline & 4 & 19 & 42.3 & 39.6 & 7.95 & 50 & 7.89 & 16.06 & 12.4 & 24.98 & 1.3 & 2.28 \\
\hline & 5 & 19 & 38.8 & 42.5 & 8.25 & 150 & 7.14 & 16.54 & 0 & 5.85 & 1.42 & 8.76 \\
\hline & 6 & 19.2 & 40.2 & 43.1 & 8.3 & 250 & 7.87 & 16.7 & 10.4 & 1.63 & 0.03 & 1.03 \\
\hline & 7 & 19 & 40.4 & 41.8 & 8.35 & 250 & 8.45 & 22.76 & 4 & 1.49 & 0.22 & 1.02 \\
\hline & $A v$ & 19.53 & 39.13 & 41.17 & 8.08 & 148.57 & 7.33 & 17.06 & 12.97 & 8.64 & 0.85 & 5.1 \\
\hline \multirow{8}{*}{ Autumn (2010) } & 1 & 27 & 36.4 & 39.3 & 8.37 & 140 & 3.32 & 9.78 & 1.2 & 53.18 & 12.41 & 18.2 \\
\hline & 2 & 27 & 32.2 & 39 & 8.03 & 45 & 2.84 & 8.32 & 1.2 & 8.55 & 1.34 & 12.14 \\
\hline & 3 & 27 & 32.7 & 38 & 8.03 & 90 & 2.84 & 7.5 & 1.2 & 15.39 & 5.7 & 16.12 \\
\hline & 4 & 27 & 34.3 & 37 & 8.27 & 125 & 4.62 & 13.83 & 4.4 & 42.78 & 4.91 & 39.26 \\
\hline & 5 & 26.5 & 22.3 & 33.2 & 7.76 & 75 & 1.79 & 4.48 & 10.4 & 6.93 & 5.15 & 22.2 \\
\hline & 6 & 27 & 19.6 & 38 & 7.6 & 110 & 1.7 & 4.77 & 4 & 21.16 & 6.06 & 9.07 \\
\hline & 7 & 28 & 38 & 39.2 & 8.31 & 150 & 6.08 & 18.05 & 23.6 & 57.92 & 6.02 & 5.27 \\
\hline & $\operatorname{Av}(1-7)$ & 27.07 & 30.21 & 37.67 & 8.05 & 105 & 3.31 & 9.53 & 6.57 & 29.42 & 5.94 & 17.46 \\
\hline \multirow{8}{*}{ Winter (2011) } & 1 & 19 & 29.4 & 40 & 8.2 & 70 & 5.03 & 25.14 & 16 & 108.75 & 13.16 & 137 \\
\hline & 2 & 20 & 24.3 & 39.7 & 7.8 & 70 & 4.05 & 20.27 & 10.4 & 24.19 & 242.78 & ND \\
\hline & 3 & 19 & 24.4 & 39.3 & 7.36 & 70 & 3.9 & 16.25 & 18.4 & 55.24 & 24.83 & 168.64 \\
\hline & 4 & 20 & 31.7 & 39 & 7.85 & 60 & 7.3 & 20.37 & 0 & 241.91 & 107.99 & ND \\
\hline & 5 & 18 & 39.3 & 40.1 & 8.43 & 180 & 10.22 & 20.44 & 3.2 & 128.04 & 14.43 & 159.62 \\
\hline & 6 & 19 & 36.8 & 40 & 8.3 & 160 & 9.58 & 28.55 & 24.8 & 152.99 & 66.12 & 283.91 \\
\hline & 7 & 18 & 40 & 40 & 8.5 & 370 & 9.18 & 29.79 & 10.4 & 40.03 & 25.83 & 153.98 \\
\hline & Av & 19 & 32.27 & 39.73 & 8.06 & 140 & 7.04 & 22.97 & 11.89 & 107.31 & 70.74 & 180.63 \\
\hline \multirow{3}{*}{ Summer (2011) } & 1 & 29 & 20.1 & 38.5 & 8.97 & 135 & 22.26 & 111.29 & 16 & 91.53 & 2.54 & 86.63 \\
\hline & 2 & 29 & 24.1 & 38.4 & 8.29 & 65 & 6.45 & 27.42 & 12 & 22.34 & 107.21 & ND \\
\hline & 3 & 28.5 & 15.1 & 38.3 & 7.75 & 50 & 0.65 & 3.23 & 20.8 & 47.22 & 4.49 & 98.26 \\
\hline
\end{tabular}


Table 2a. Seasonal variations of hydrographical parameters at El-Mex Bay (2010-2011).

\begin{tabular}{|c|c|c|c|c|c|c|c|c|c|c|c|c|}
\hline & \multirow{2}{*}{ Stations } & \multirow{2}{*}{ Temp. $\left({ }^{\circ} \mathbf{C}\right)$} & \multicolumn{2}{|c|}{ Salinity } & \multirow{2}{*}{ pH } & \multirow{2}{*}{ Transp. (cm) } & \multirow{2}{*}{$\mathrm{DO}$ mg/L } & \multirow{2}{*}{ BOD mg/L } & \multirow{2}{*}{ OOM mgO/L } & \multirow{2}{*}{\multicolumn{2}{|c|}{$\frac{\text { Chl-b }}{\mu \mathrm{g} / \mathrm{L}}$}} & \multirow[t]{2}{*}{ Chl-c } \\
\hline & & & Surface & sub & & & & & & & & \\
\hline \multirow{5}{*}{ Season } & 4 & 28.5 & 14.5 & 37.7 & 7.84 & 30 & ND & ND & 9.6 & 202.57 & 36.65 & ND \\
\hline & 5 & 28 & 28.8 & 38.4 & 8.27 & 105 & 6.45 & 32.26 & 8 & 107.75 & 3.42 & 101.14 \\
\hline & 6 & 28.5 & 30.7 & 38 & 8.33 & 100 & 6.45 & 32.26 & 1.6 & 129.85 & 14.92 & 169.61 \\
\hline & 7 & 28 & 36.7 & 38.3 & 8.34 & 100 & 3.87 & 19.35 & 5.6 & 34.48 & 5.97 & 88.46 \\
\hline & $A v$ & 28.5 & 21.43 & 38.23 & 8.26 & 83.57 & 6.59 & 37.63 & 10.51 & 90.82 & 25.03 & 108.82 \\
\hline \multirow{8}{*}{ Average for 4 seasons } & 1 & 24 & 29.63 & 40.03 & 8.24 & 121.25 & 9.97 & 41.59 & 16.9 & 64.59 & 7.03 & 60.46 \\
\hline & 2 & 24 & 29.8 & 40.03 & 8.04 & 82.5 & 4.57 & 17.1 & 11.9 & 17.88 & 87.96 & 5.1 \\
\hline & 3 & 23.5 & 27.8 & 37.88 & 7.85 & 65 & 3.29 & 10.44 & 11.5 & 30.77 & 9.15 & 73.07 \\
\hline & 4 & 23.63 & 28.2 & 30.83 & 7.98 & 66.25 & 4.95 & 16.75 & 6.6 & 128.06 & 37.71 & 10.39 \\
\hline & 5 & 22.88 & 32.3 & 38.55 & 8.18 & 127.5 & 6.4 & 18.43 & 5.4 & 62.14 & 6.1 & 72.93 \\
\hline & 6 & 23.43 & 31.83 & 39.78 & 8.13 & 155 & 6.4 & 20.57 & 10.2 & 76.41 & 21.78 & 115.91 \\
\hline & 7 & 23.25 & 38.5 & 39.83 & 8.38 & 217.5 & 6.9 & 22.49 & 10.9 & 33.48 & 9.51 & 62.18 \\
\hline & $A v$ & 23.53 & 30.76 & 38.13 & 8.11 & 119.29 & 6.07 & 21.8 & 10.49 & 59.05 & 25.61 & 57.15 \\
\hline
\end{tabular}

Nubaria drains at the period of 2010/2011.

\section{Dissolved oxygen (DO)}

Dissolved oxygen is frequently the key parameter in determining the extent and kinds of life in a water body. The distribution of DO in waste water attained its minimum average of $2.02 \mathrm{mg} / \mathrm{L}$ (St.8) during spring, tended to increase during summer, $5.48 \mathrm{mg} / \mathrm{land}$ during winter, $6.13 \mathrm{mg} / \mathrm{L}$ reaching a maximum level of $7.14 \mathrm{mg} / \mathrm{L}$ (St.10) in autumn, with an average for the 4 seasons of 4.57 $\mathrm{mg} / \mathrm{L}($ Table $2 \mathrm{a})$. The amount of $\mathrm{DO}$ in seawater station fluctuated between a minimum of 0.65 $\mathrm{mg} / \mathrm{L}$ (St.3) and a maximum of $22.26 \mathrm{mg} / \mathrm{L}$ (St.1) which was recorded during summer, with an average for the 4 seasons of $6.07 \mathrm{mg} / \mathrm{L}$ (Table 2a).

The smallest values were detected in the drains that ranged from ND to $7.14 \mathrm{mg} / \mathrm{L}$ (Table $2 \mathrm{~b}$ ); coincided with the consumption of oxygen in the decomposition of organic matter (Whaby and Shreadah, 1984; Said et al., 1994; Tayel et al.; 1996; Fahmey et al., 1997). DO concentrations of the present study are compared to previous studies in El Mex area by Hamdy et al. (2014); Okbah et al. (2013); Shredeah et al. (2013) with reported ranges of 4.4-14.6, 1.17-8.45, 1.11-4.66. Shreadah (2006a, b), Mahmoud et al. (2005) and Tayel et al. (1996) reported average values of $4.29,12.3$ and 6.81 $\mathrm{mg} / \mathrm{L}$ respectively.

\section{Biological oxygen demand (BOD)}

The amount of dissolved oxygen which is consumed during organic matter degradation, gave a general picture of allochthonous organic load (Whaby and Shriadah, 1984). Table2a demonstrates that seasonal variations of BOD occurred at El-Mex Bay stations whereas the maximum average of $111.29 \mathrm{mg} / \mathrm{Land}$ minimum ND were observed during summer at stations 1 and 4 respectively, with an average for the 4 seasons of $21.80 \mathrm{mg} / \mathrm{L}$ for El Mex Bay (Table 2a). A range of seasonal variations at waste water sites was reported $11.98-36.9 \mathrm{mg} / \mathrm{L}$ at stations 11 and 9 respectively (Table $2 b$ ). Generally, when BOD levels are high, there is a decline in DO 
Table 2b. Seasonal variations of hydrographical parameters at drains (2010-2011).

\begin{tabular}{|c|c|c|c|c|c|c|c|c|c|c|c|}
\hline \multirow{2}{*}{ Season } & \multirow{2}{*}{ Stations } & \multirow{2}{*}{$\begin{array}{c}\text { Temperature } \\
\left({ }^{\circ} \mathrm{C}\right)\end{array}$} & \multirow{2}{*}{ Salinity } & \multirow{2}{*}{ pH } & \multirow{2}{*}{ Transp. (cm) } & \multirow{2}{*}{$\mathrm{DO}(\mathrm{mg} / \mathrm{L})$} & \multirow{2}{*}{ BOD (mgL) } & \multirow{2}{*}{$\begin{array}{c}\text { OOM } \\
(\mathrm{mgO} / \mathrm{L})\end{array}$} & Chl-a & Chl-b & $\mathrm{Chl}-\mathrm{C}$ \\
\hline & & & & & & & & & \multicolumn{3}{|c|}{$\mu \mathrm{g} / \mathrm{L}$} \\
\hline \multirow{4}{*}{ Spring } & 8 & 23.6 & 2.8 & 8.01 & 15 & 2.02 & 12.6 & 14.84 & 7.98 & 0.65 & 0.65 \\
\hline & 9 & 25 & 1.1 & 7.53 & 15 & ND & 28.8 & 58.2 & 7.72 & 1.75 & 1.17 \\
\hline & 10 & 23.6 & 0.3 & 8.41 & 15 & ND & 20.35 & 12.2 & 0.92 & 0.01 & 0.01 \\
\hline & 11 & 23.6 & 2.8 & 8.56 & 20 & 3.2 & 11.98 & ND & 9.22 & 0.92 & 0.92 \\
\hline \multirow{4}{*}{ Autumn } & 8 & 28.9 & 6.2 & 7.57 & 25 & 6.82 & 27.4 & 14.4 & 6.24 & 1.76 & 1.76 \\
\hline & 9 & 30.9 & 2.6 & 7.16 & 10 & ND & 30.5 & 40.8 & 1.87 & 1.81 & 1.81 \\
\hline & 10 & 28.9 & 7.3 & 7.55 & 50 & 7.14 & 29.98 & 7.2 & 6.47 & 8.53 & 8.53 \\
\hline & 11 & 29 & 6 & 7.69 & 25 & 6.98 & 26.89 & 15.2 & 4.68 & 1.32 & 1.32 \\
\hline \multirow{4}{*}{ Winter } & 8 & 15 & 4.2 & 8.16 & 30 & 6.13 & 24.19 & 8 & 35.71 & 5 & 6.21 \\
\hline & 9 & 18 & 1.7 & 8.02 & 5 & ND & 36.9 & 112 & 9.17 & 10.64 & 19.7 \\
\hline & 10 & 16 & 4.2 & 8 & 30 & 3.55 & 17.69 & 40 & 1.43 & 42.16 & 5.45 \\
\hline & 11 & 17 & 5.4 & 8.58 & 50 & 6.13 & 25.81 & 2.4 & ND & 3.75 & ND \\
\hline \multirow{4}{*}{ Summer } & 8 & 28 & 4.9 & 8.15 & 30 & 5.48 & 24.19 & 11.2 & 186.83 & ND & ND \\
\hline & 9 & 29 & 1.3 & 7.63 & 5 & ND & 29.8 & 8 & 29.3 & 8.18 & 8.18 \\
\hline & 10 & 28 & 3.2 & 7.94 & 50 & 2.9 & 13.42 & 52.8 & ND & ND & ND \\
\hline & 11 & 28 & 1.6 & 7.79 & 100 & ND & 23.85 & 27.2 & ND & ND & ND \\
\hline \multirow{4}{*}{$\begin{array}{l}\text { Average for } 4 \\
\text { seasons }\end{array}$} & 8 & 23.88 & 4.53 & 7.97 & 19.03 & 5.11 & 22.1 & 12.11 & 59.19 & 1.85 & 2.87 \\
\hline & 9 & 25.73 & 1.68 & 7.59 & 7.53 & ND & 31.5 & 54.75 & 12.02 & 5.6 & 7.72 \\
\hline & 10 & 24.13 & 3.75 & 7.98 & 26.71 & 4.53 & 20.36 & 28.05 & 2.2 & 12.68 & 4.66 \\
\hline & 11 & 24.4 & 3.95 & 8.16 & 34.86 & 4.08 & 22.13 & 14.93 & 3.47 & 1.5 & 1.12 \\
\hline
\end{tabular}

levels. This is because the demand for oxygen by the bacteria is high and they are taking oxygen from the oxygen dissolved in the water (Whaby and Shreadah, 1984). If there is no organic waste present in the water, there would not be as many bacteria present to decompose it and thus the BOD will tend to be lower and the DO level will tend to be higher. The present study recorded values higher than that recorded by Hamdy et al.
2014 (1.1-5.7 mg/ L) in El Mex region. Fathy et al. (2012) recorded a range of $4.84-30.56 \mathrm{mg} / \mathrm{L}$ for $\mathrm{El}$ Nubaria and EI Umum drains for winter and summer region in the period 2010 to 2011.

\section{Oxidizable organic matter (OOM)}

Organic matter plays a major role in aquatic systems. It affects biogeochemical processes, nutrient cycling, biological availability, andchemical transport and interactions (Cole, 1979). Oxidizable organic matter has been used as basic water quality parameter to assess organic pollution. Organic matter can come from allocthonous source: which are brought to aquatic system by river runoff, with smaller atmospheric transport (Chester, 2000) or autochthonous sources such as excretion of organic matter are driven by living organisms and 
decomposition of dead organisms and detritus via long chain of decom-position processes (Duursma, 1961). The seasonal varia-tion of OOM occurred at drains where the maximum of $112.00 \mathrm{mgO}_{2} / \mathrm{L}$ and minimum of ND were observed during winter at station 9 and spring 2010 at station 11 , respectively (Table $2 b$ ).

A range of seasonal values at El-Mex Bay stations was reported $\left(0-34.4 \mathrm{mgO}_{2} / \mathrm{L}\right)$, with an average for the 4 seasons of $10.49 \mathrm{mgO}_{2} / \mathrm{L}$, the values of $\mathrm{OOM}$ at waste water stations were nearly doubled that at seawater site. The increasing organic supply introduced into the restricted studied area under relative slow rate of self-purification (Shriadah and Emara 1992a,b, Said et al. 1994, Fahmey et al. 1997, Shriadah et al. 2006a,b, Shaltout 2008, Fathy et al. 2012) results in elevation of OOM content at El-Mex Bay (Table 2a). OOM concentrations of the present study are comparable with those of Okbah et al. (2013); Shreadah et al. (2013); Nessim et al. (2010) with ranges of 0.96-8.4, 5.2-38.4 and 5.44-14.56 $\mathrm{mgO}_{2} / \mathrm{L}$ respectively.

The type of wastewater discharge can be determined according to BOD/ OOM (ECPH, 1975). If it is $1: 1$, it is characteristic of well purified water; the biodegradable compounds have a ratio of $\leq 2: 1$ while that of 2:1-4:1 is specific for crude domestic sewage, carbohydrates and proteins enriched wastes (food processing wastes) have ratios equal or greater than those for sewage. In the present study, the annual mean BOD/OOM ratios is amounted to $1.95: 1$, this may indicate that most of the sewage wastes reaching the investigated region had a biodegradable character.

\section{Chlorophylls-a, b and c}

\section{Chl-a}

It is considered as the main pigment that can be used for the determination of phytoplankton biomass (Carlson, 1977). The levels of Chl-a in El-Mex Bay showed wide variations (Table $2 \mathrm{a}$ ). These were fluctuated between $1.49 \mu \mathrm{M} / \mathrm{L}$ in spring 2010 at station 7 and $241.91 \mu \mathrm{M} / \mathrm{L}$ in winter 2011 at station 4 . The values of the chlorophyll-a in El-Mex drains were fluctuated between ND in summer at drains 10 and 11 and $186.83 \mu \mathrm{M} / \mathrm{L}$ in summer at drain 8 (Table $2 b$ ). The present study recorded that range of Chl-a exceed that recorded by Faragallah et al. 2009 in Eastern Harbour (0.41-78.68 $\mu \mathrm{M} / \mathrm{L})$ and that recorded by Emara et al. (1992) in El Mex Bay (0.00-5.56 $\mu \mathrm{M} / \mathrm{L})$.

In general, the high values of Chlorophyll-concentrations of the present study are higher than those of Shams-El Din and Dorgham (2007) for Abu Qir Bay which reported values of $14.9 \mu \mathrm{g} / \mathrm{L}$ in the investigated area reflect signs of eutrophication which is used as an estimation of the standing phytoplankton crop.

\section{Chl-b}

It is a form of chlorophyll. It helps in photosynthesis by absorbing light energy. It is more soluble than chlorophyll $a$ in polar solvents because of its carbonyl group. The levels of Chl-b in El- Mex Bay showed wide variations. They fluctuated between $0.03 \mu \mathrm{M} / \mathrm{L}$ in spring 2010 at station 6 (In front of the Western Harbour) and 242.78 $\mu \mathrm{M} / \mathrm{L}$ in winter 2011 at station 2 [El- Hexane Factory (cooling station)] may due to water temperature beside the wastes Table $2 a$. The average values of chlorophyll-b in El-Mex drains were fluctuated between ND at drains 8,10 and 11 in summer 2011 and $42.16 \mu \mathrm{M} / \mathrm{L}$ in winter ElNubaria drain Table $2 b$.

\section{Chl-c}

It is found in certain marine algae, such as diatoms and dinoflagellates. The levels of Chl-c in El-Mex Bay showed wide variations (Table 2a). These were fluctuated between $0.54 \mu \mathrm{M} / \mathrm{L}$ in spring 2010 at station 5 (Far $500 \mathrm{~m}$ from ElUmoum Drain) and $283.91 \mu \mathrm{M} / \mathrm{L}$ in winter 2011 at station 6 [In front of Western Harbour]. The regional mean values of $\mathrm{Chl}-\mathrm{c}$ were increased in waste water, at which it is directly in front of the Western Harbour beside ElUmum drain. The average values of the chlorophyll-c in El-Mex drains fluctuated between $0.01 \mu \mathrm{M} / \mathrm{L}$ in spring at drain 10 and $19.70 \mu \mathrm{M} / \mathrm{L}$ in winter at El Qalaa drain (Table 2b).

\section{Nutrient salts}

Nutrient salts are considered as very important compounds essential for the living organisms in natural waters. These are chemical substances used for maintenance and growths of biota, which are critical for survival of organisms. Essential nutrients, $\mathrm{N}$ and $\mathrm{P}$ are of particular concern in aquatic systems, because their availability can limit the growth of aquatic. Nutrients represent the fertility of water, on which primary productivity and, ultimately fish production depend on it. Moreover, the amount of autotrophic producers is a function of the nutrient concentrations. This relation has often been considered as the main determinant of the dynamics of aquatic systems and persisting presence of algae in great numbers Cloern (2001).

\section{Inorganic nitrogen species $\left(\mathrm{NH}_{4}-\mathrm{N}, \mathrm{NO}_{2}-\mathrm{N}\right.$ and $\left.\mathrm{NO}_{3}-\mathrm{N}\right)$}

Dissolved inorganic nitrogen concentrations DIN (the sum of ammonia, nitrite and nitrate) in the bay water were relatively high. Generally, the high levels of DIN were affected directly by the discharged water from the drains, which were containing high amounts of agricultural fertilizers.

Ammonia $\left(\mathrm{NH}_{4}{ }^{+}-\mathrm{N}\right)$ : Ammonia is a highly variable parameter quickly produced and processed by the bacterial 
decomposition of organic matter (ammonification), the production of $\mathrm{NH}_{4}^{+}$as an excretory product, especially from zooplankton and its production by bacterial reduction of $\mathrm{NO}_{2}^{-}$and $\mathrm{NO}_{3}^{-}$(nitrogen-immobilization). In principle, $\mathrm{NH}_{4}{ }^{+}$salts are the form of $\mathrm{N}$ preferred by algae and only when $\mathrm{NH}_{4}^{+}$concentrations are depleted to < $0.0021 \mathrm{mg} / \mathrm{l}, \mathrm{NO}_{3}^{-}$and $\mathrm{NO}_{2}^{-}$will be utilized (Unesco, $\mathrm{FAO}, 1988)$. Ammonia is discharged into water bodies through industrial wastes and as a product of municipal or community wastes as well as agricultural wastes where ammonia containing fertilizers are used.

Ammonium nitrogen exists in aqueous solution either

as ammonium ion $\left(\mathrm{NH}_{4}^{+}\right)$or as ammonia $\left(\mathrm{NH}_{3}\right)$ depending on the $\mathrm{pH}$ of the solution, in accordance with the following equilibrium reaction:

\section{$\mathrm{NH}_{3}+\mathrm{H}_{2} \mathrm{O} \quad \longleftrightarrow \quad \mathrm{NH}_{4}^{\top}+\mathrm{OH}^{-}$}

At $\mathrm{pH}$ above 7, the equilibrium is displaced to the left. At $\mathrm{pH}<7, \mathrm{NH}_{4}{ }^{+}$is predominant.

Ammonia is the majority of dissolved inorganic nitrogen (DIN) for both waste and sea waters. It represented a ratio of 3.14 to $98.86 \%$ from DIN respectively (Table 3a and b; Figures 3 to 4). Seasonal and regional distribution of ammonia is illustrated in Table $3 a$ and $b$. The high concentration of ammonia at waste water stations is derived from decomposition of a huge amount of organic matter, domestic, agriculture and industrial effluents. The striking increase in the amount of ammonia observed at El Qalaa was accompanied by anoxic condition, high OOM and low DO content. Almost all the combined inorganic nitrogen in anoxic waters was found as ammonia ions, while $\mathrm{NO}_{2}$ disappeared and $\mathrm{NO}_{3}$ ions were in a relative low concentration (Riley and Chester, 1971). El-Umoum site had much lower ammonia content in accordance with Nessim et al. (2010) which recorded concentration range of 14.40 to $61.4 \mu \mathrm{M} / \mathrm{L}$ during 2007/2008. With respect to El-Mex Bay (St.4) during summer represented the highest level $(233.30 \mu \mathrm{M} / \mathrm{L})$ while spring gave the lowest one $(0.15 \mu \mathrm{M} / \mathrm{L})$, with an average for the 4 seasons of $74.29 \mu \mathrm{M} / \mathrm{L}$. Mahmoud et al. (2005) recorded average concentration of $227.35 \mu \mathrm{M} / \mathrm{L}$ in El Mex region during 2003/2004. El-Mex water is enriched with ammonia during spring-summer period. The high ammonia concentration in these seasons could be attributed to waste water discharge through ElUmoum Drain as well as planktonic animals excretions.

Nitrite: It is a minor constituent of DIN which consist of 5.2 to $11.8 \%$ for waste and sea waters, respectively and is characterized as intermediate compound which could be derived either from the oxidation of ammonia or reduction of nitrate and can be removed from solution during nitrogen assimilation by phytoplankton. Regionally, absence of nitrite is accompanied by an increase in ammonia at Mariut station during spring. The maximum concentration of nitrite during summer period may be attributed to the excretion of extracellular nitrite by phytoplankton (Riley and Chester, 1971). It may also influence the distribution of nitrite within the surface layers of natural waters (Hutchinson, 1957). High averages reported during spring at waste and sea water locations may be due to allochthonous inputs by ElUmoum drain, in addition to autochthonous source resulting from decaying of organic matter and oxidation processes (Figures 3 to 4). Seasonal variations in nitrite concentration in waste water appeared to range from $0.28 \mu \mathrm{M} /$ Lduring winter at El-Qalaa drain to $20.25 \mu \mathrm{M} / \mathrm{L}$ during summer at El-Nubaria drain, with an average for the 4 seasons of $5.11 \mu \mathrm{M} / \mathrm{L}$ (Table $3 \mathrm{~b}$ ). With respect to El-Mex Bay, nitrite showed a maximum concentration of $22.85 \mu \mathrm{M} / \mathrm{L}$ and a minimum of $0.3 \mu \mathrm{M} / \mathrm{L}$ during spring and summer, respectively, with an average for the 4 seasons of $4.74 \mu \mathrm{M} / \mathrm{L}$ (Table 3a). Compared the data in present study with previous studies, Nessim et al. (2010) recorded a range from 7.4 to $11.1 \mu \mathrm{M} / \mathrm{Lfor}$ waste water and 1.8 to 11.3 for El Mex Bay. Mahmoud et al. (2005) recorded average value of $14.32 \mu \mathrm{M} / \mathrm{L}$ for El Mex area.

Nitrate: Sillen (1961) denoted that nitrate is considered to be the only stable oxidation level in the presence of oxygen in water. It comprises about 1.75 to $17.4 \%$ of DIN in waste and sea waters, respectively (Table 2 and Figure 2). The decrease of nitrate in this study at El-Mex bay stations during summer could be attributed to two factors; the first is the assimilation by plants and the second is denitrification (i.e. the reduction of nitrate to nitrite before releasing $\mathrm{N}_{2} \mathrm{O}$ or $\mathrm{N}_{2}$ - molecules (Hutchinson, 1957). Nitrate concentrations in El Mex Bay showing arrange of ND to 56.22 at stations 5 and 6 in summer and Autumn, respectively. Emara et al. (1995) reported Nitrate concentration of $7.33 \pm 4.4 \mu \mathrm{M} / \mathrm{L}$. While, for waste water it ranged from $0.46 \mu \mathrm{M} / \mathrm{L}$ at El- Umum to $58.42 \mu \mathrm{M} / \mathrm{L}$ at El- in Qalaa drain in Autumn at Summer seasons respectively. Autumn exhibited relative higher values greater than any other season ,this result is in agreement with those of Nessim et al. (2010) in El Mex area during 2007/2008 which recorded range of $6.3-21 \mu \mathrm{M} / \mathrm{L}$ and average value of $13.3 \mu \mathrm{M} / \mathrm{L}$. Much higher average value of $\mathrm{NO}_{3}(82.75 \mu \mathrm{M} / \mathrm{L})$ was recorded by Mahmoud et al. (2005) in El Mex region in 2003/2004. Based on the estimations of El Gindy et al. (1986); Nitrate flux to the sea at El Mex Bay was 878 kilograms.

\section{Reactive phosphorus $\left(\mathrm{PO}_{4}\right)$}

Phosphorus is an essential and sometimes limiting fac 
Table 3a. Nutrient salts $(\mu \mathrm{M} / \mathrm{L})$ concentration at El-Mex area (2010-2011).

\begin{tabular}{|c|c|c|c|c|c|c|c|}
\hline Seasons & Stations & $\mathrm{NH}_{3} / \mathrm{N}$ & $\mathrm{NO}_{2} / \mathrm{N}$ & $\mathrm{NO}_{3} / \mathrm{N}$ & DIN & $\mathrm{PO}_{4} / \mathrm{P}$ & $\mathrm{SiO}_{4} / \mathrm{Si}$ \\
\hline \multirow{8}{*}{ Spring (2010) } & 1 & 171.25 & 0.63 & 1.17 & 173.04 & 5.04 & 19.94 \\
\hline & 2 & 32.8 & 2.43 & 1.3 & 36.52 & 1.58 & 11.51 \\
\hline & 3 & 39.8 & 4.53 & 0.21 & 44.53 & 30.45 & 12.03 \\
\hline & 4 & 13 & 22.85 & 6.05 & 41.9 & 11.59 & 30.6 \\
\hline & 5 & ND & 2.83 & 1.96 & 4.79 & 2.56 & 8.55 \\
\hline & 6 & 13.2 & 1.95 & 4.43 & 19.58 & 1.05 & 4.22 \\
\hline & 7 & 0.15 & 0.73 & 1.91 & 2.78 & 1.61 & 5.07 \\
\hline & av & 45.03 & 5.13 & 2.43 & 46.16 & 7.7 & 13.13 \\
\hline \multirow{8}{*}{ Autumn (2010) } & 1 & 10.3 & 0.68 & 8.4 & 19.37 & 0.98 & 4.11 \\
\hline & 2 & 58.05 & 3.55 & 8.01 & 69.61 & 1.44 & 32.78 \\
\hline & 3 & 55.4 & 3.13 & 47.95 & 106.47 & 1.47 & 27.57 \\
\hline & 4 & 26.5 & 2.5 & 10.1 & 39.1 & 1.33 & 14.84 \\
\hline & 5 & 111.1 & 12.73 & 49.49 & 173.32 & 0.88 & 88.73 \\
\hline & 6 & 119.9 & 6 & 56.22 & 182.12 & 3.92 & 99.86 \\
\hline & 7 & 31.9 & 2.4 & 17.98 & 52.28 & 1.23 & 13.76 \\
\hline & av & 59.02 & 4.43 & 28.31 & 91.75 & 1.61 & 40.23 \\
\hline \multirow{8}{*}{ Winter 2011} & 1 & 0.5 & 7.6 & 7.8 & 15.9 & 5.85 & 16.13 \\
\hline & 2 & 2.2 & 11.75 & 9.17 & 23.12 & 7.56 & 38.59 \\
\hline & 3 & 3.6 & 12.18 & 6.98 & 22.75 & 8.33 & 38.59 \\
\hline & 4 & 8.65 & 5.08 & 8.51 & 22.23 & 2.87 & 10.92 \\
\hline & 5 & ND & 0.5 & 0.96 & 1.46 & 2.1 & ND \\
\hline & 6 & ND & 2.03 & 8.11 & 10.14 & 2.17 & 3.29 \\
\hline & 7 & ND & 0.73 & 4.93 & 5.66 & 2.52 & 0.48 \\
\hline & av & 3.74 & 5.69 & 6.64 & 14.46 & 4.49 & 18 \\
\hline \multirow{8}{*}{ Summer (2011) } & 1 & 113.1 & 7.35 & 6.24 & 128.25 & 0.7 & 1.22 \\
\hline & 2 & 170.9 & 6.73 & 6.7 & 186.79 & 2.45 & 33.63 \\
\hline & 3 & 216.9 & 0.63 & 0.58 & 224.5 & 8.86 & 57.79 \\
\hline & 4 & 233.3 & 0.3 & 0.2 & 242.11 & 12.25 & 50.39 \\
\hline & 5 & 126.3 & 2 & ND & 129.26 & 2.21 & 23.16 \\
\hline & 6 & 75.1 & 2.93 & 0.31 & 86.14 & 1.79 & 16.84 \\
\hline & 7 & 96.5 & 6.15 & 1.4 & 107.58 & 1.4 & 30.12 \\
\hline & av & 147.44 & 3.73 & 2.57 & 157.8 & 4.24 & 30.45 \\
\hline \multirow{8}{*}{$\begin{array}{l}\text { average foe the } 4 \\
\text { seasons }\end{array}$} & 1 & 73.79 & 4.06 & 5.9 & 84.14 & 3.14 & 14.08 \\
\hline & 2 & 65.99 & 6.11 & 6.29 & 79.01 & 3.26 & 30.37 \\
\hline & 3 & 78.93 & 5.11 & 13.93 & 99.56 & 12.28 & 29.19 \\
\hline & 4 & 70.36 & 7.68 & 6.21 & 86.33 & 7.01 & 16.82 \\
\hline & 5 & 118.7 & 4.51 & 13.1 & 77.2 & 1.93 & 48.64 \\
\hline & 6 & 69.4 & 3.23 & 17.27 & 74.49 & 2.23 & 27.67 \\
\hline & 7 & 42.85 & 2.5 & 6.56 & 42.08 & 1.69 & 4.95 \\
\hline & av & 74.29 & 4.74 & 9.89 & 77.55 & 4.51 & 24.53 \\
\hline
\end{tabular}

nutrient for maintenance of aquatic life. When it found in large content, it produces eutrophication condition which is considered as a potential pollutant. The high enrichment of wastewater with phosphate during winter- spring period is mainly attributed to the allochthonous huge amount of domestic and drainage effluents enriched with phosphate and other fertilizers discharge into this area (Said et al., 1994; Fahmey et al., 1997). The release 
Table 3b. Nutrient Salts $(\mu \mathrm{M} / \mathrm{L})$ concentrations in El Mex drains 2010-2011.

\begin{tabular}{|c|c|c|c|c|c|c|c|}
\hline Seasons & Stations & $\mathrm{NH}_{3} / \mathrm{N}$ & $\mathrm{NO}_{2} / \mathrm{N}$ & $\mathrm{NO}_{3} / \mathrm{N}$ & DIN & $\mathrm{PO}_{4} / \mathrm{P}$ & $\mathrm{SiO}_{4} / \mathrm{Si}$ \\
\hline \multirow{5}{*}{ Spring (2010) } & 8 & 65.1 & 12.33 & 9.88 & 87.3 & 4.83 & 77.59 \\
\hline & 9 & 726.25 & 0.63 & 2.65 & 729.53 & 26.95 & 49.84 \\
\hline & 10 & 89.6 & 1.38 & 1.59 & 92.57 & 0.84 & 6.18 \\
\hline & 11 & 53.5 & 0.33 & 20.06 & 73.88 & 5.11 & 111 \\
\hline & av & 233.61 & 3.66 & 8.55 & 245.82 & 9.43 & 61.15 \\
\hline \multirow{5}{*}{ Autumn (2010) } & 8 & 63.4 & 1.08 & 41.18 & 105.65 & 2.63 & 111 \\
\hline & 9 & 1820 & 1.93 & 58.42 & 1880.34 & 9.59 & 99.86 \\
\hline & 10 & 193.4 & 8.38 & 28.56 & 230.33 & 0.77 & 111 \\
\hline & 11 & 87.6 & 1.3 & 39.83 & 128.73 & 1.16 & 111 \\
\hline & av & 541.1 & 3.17 & 42 & 586.26 & 3.54 & 108.22 \\
\hline \multirow{5}{*}{ Winter 2011} & 8 & 196.4 & 9.88 & 28.37 & 234.65 & 18.31 & 2.15 \\
\hline & 9 & 2815.85 & 0.28 & 3.76 & 2819.88 & 18.06 & 16.28 \\
\hline & 10 & 207 & 16.08 & 25.14 & 248.22 & 21.67 & 0.63 \\
\hline & 11 & 228.4 & 1.25 & 12.58 & 242.23 & 0.7 & 1.37 \\
\hline & av & 861.91 & 6.87 & 17.46 & 886.24 & 14.68 & 5.11 \\
\hline \multirow{5}{*}{ Summer (2011) } & 8 & 4.85 & 2.4 & 0.48 & 7.73 & 0.11 & 103.75 \\
\hline & 9 & 45.4 & 2.75 & 31.75 & 79.9 & 29.05 & 189.44 \\
\hline & 10 & ND & 20.25 & 29.37 & 49.62 & 4.45 & 73.41 \\
\hline & 11 & 42.9 & 1.5 & 0.35 & 44.75 & 26.67 & 2.15 \\
\hline & av & 31.05 & 6.73 & 15.49 & 45.5 & 15.07 & 92.19 \\
\hline \multirow{5}{*}{ average for the 4 seasons } & 8 & 82.44 & 6.42 & 19.98 & 108.83 & 6.47 & 73.62 \\
\hline & 9 & 1351.88 & 1.39 & 24.14 & 1377.41 & 20.91 & 88.86 \\
\hline & 10 & 163.33 & 11.52 & 21.16 & 155.18 & 6.93 & 47.8 \\
\hline & 11 & 103.1 & 1.09 & 18.21 & 122.4 & 8.41 & 56.38 \\
\hline & av & 425.19 & 5.11 & 20.87 & 440.96 & 10.68 & 66.66 \\
\hline
\end{tabular}

of large amount of phosphate during decaying and oxidation of organic substances was investigated at ElQalaa location during summer-spring period coincided with oxygen depletion which agreed with the study of Riley and Chester (1971). At El-Mex Bay area, high consumption, as expected, in phosphate ion by marine flora was observed during spring blooming. A clear maximum was recorded during summer season since most of organic load was decayed. El-Mex Bay water, influenced by land-based sources, is still too high in phosphorus content if compared with open seawater. The waste and bay waters exhibited average phosphate concentration of 10.68 and $4.51 \mu \mathrm{M} / \mathrm{L}$ respectively reflected an eutrophication condition (UNEP, 1988). The average for the 4 seasons of PO4 in waste water and $\mathrm{El}$ Mex Bay in this study is lower than average that measured by Nessim et al. (2010) and Mahmoud et al. (2005) which are 14.0 and $19.69 \mu \mathrm{M} /$ Lfor waste water and El Mex Bay water respectively.
Silicate $\left(\mathrm{SiO}_{4}\right)$ : Seasonal and regional variation of silicate are illustrated in Tables $3 a$ and $3 b$.Significant changes in silicate content were demonstrated at waste water ranging from 2.15 during Winter to $189.44 \mu \mathrm{M} / \mathrm{L}$ during Summer with an average for the 4 seasons of $66.66 \mu \mathrm{M} / \mathrm{L}$ (Table $3 \mathrm{~b}$ ). The waste water at the area of study exhibits silicate content four times greater or more (on, average) than that at seawater Figure 3 .Silicate concentration in El Mex Bay water varied from ND in winter to 99.86 in autumn with an annual averageof 24.53 $\mu \mathrm{M} / \mathrm{L}$ (Table 3a). Coastal waters have, in general, quite high silicate contents, since they are affected by landbased sources (Riley and Chester, 1971). During Autumnsummer period, El-Mex Bay water was characterized by high silicate content $>50 \mu \mathrm{M} / \mathrm{L}$ and low salinity value $<40$ as a function of discharged waters. The concentration of silicate during spring-winter period is relatively low owing to its consumption by diatoms and radiolarian. Nessim et al. (2010) recorded values that ranged from33.7 to 221.9 


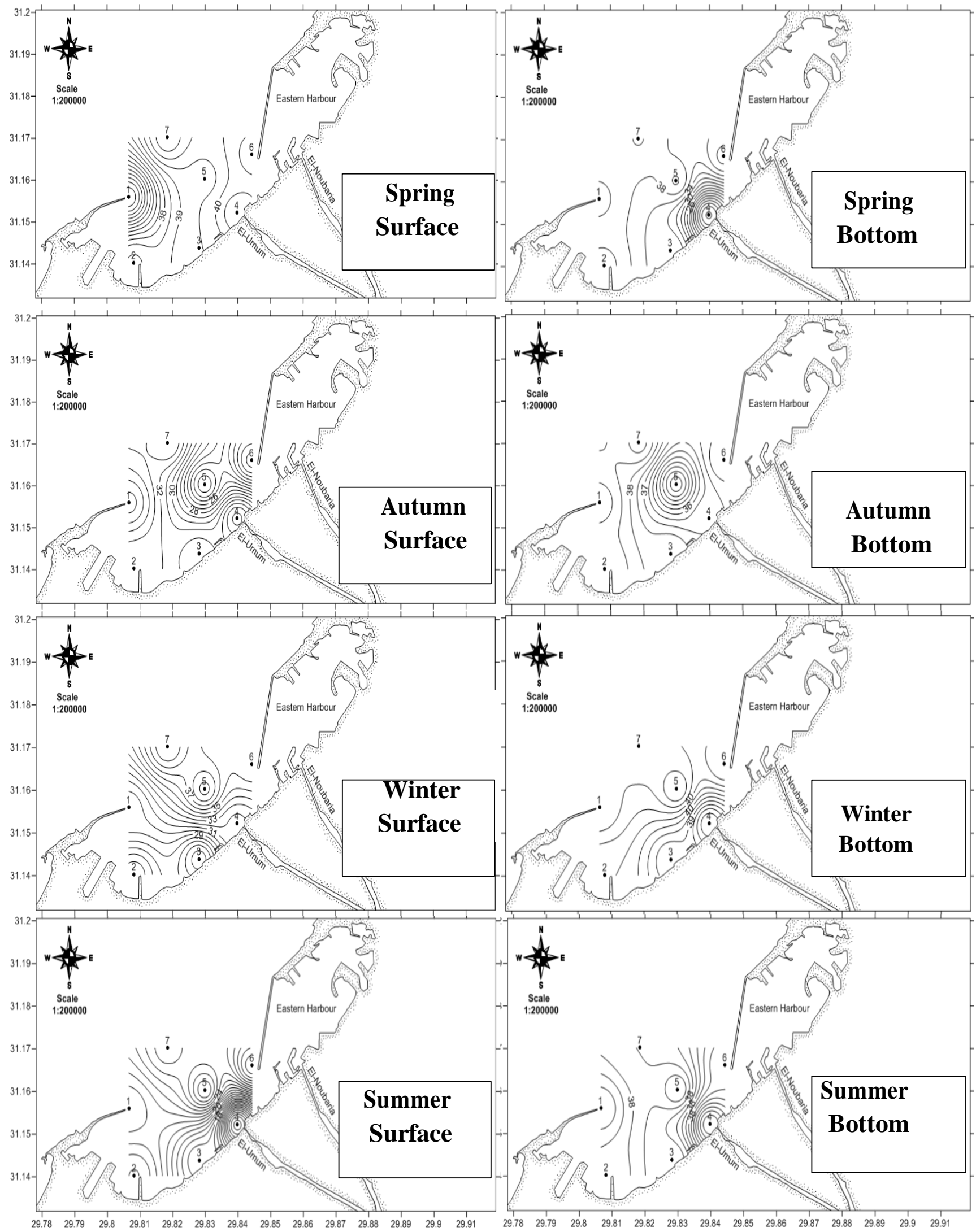

Figure 2. Horizontal distribution of salinity at surface and bottom water in El-Mex Bay. 
$\square \mathrm{NH} 3 / \mathrm{N}=\mathrm{NO} 2 / \mathrm{N}=\mathrm{NO} / \mathrm{N}=\mathrm{PO} 4 / \mathrm{P}-\mathrm{SiO} 4 / \mathrm{Si}$

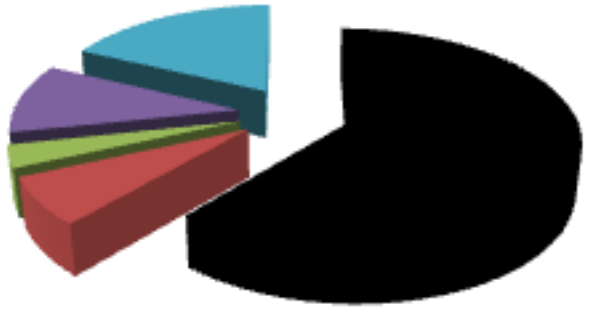

Spring 2010

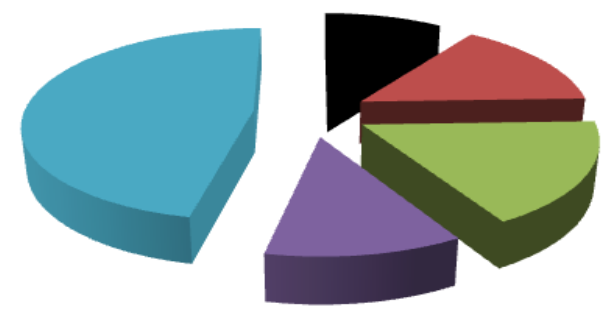

Winter 2011

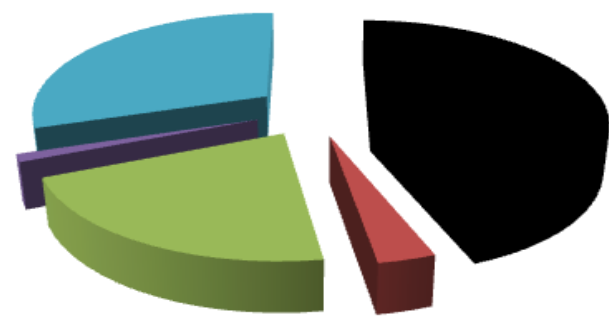

Autumn 2010

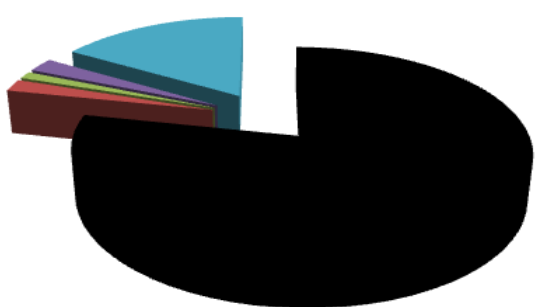

Summer 2011

Figure 3. Average Values of Seasonal Variations of nutrient salts at El Mex Bay (2010-2011).

$\because \mathrm{NH} 3 / \mathrm{N} \square \mathrm{NO} 2 / \mathrm{N} \backsim \mathrm{NO} / \mathrm{N} \backsim \mathrm{PO} 4 / \mathrm{P} \backsim \mathrm{SiO} 4 / \mathrm{Si}$

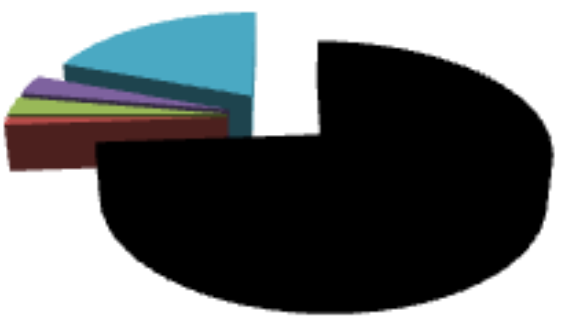

Spring 2010

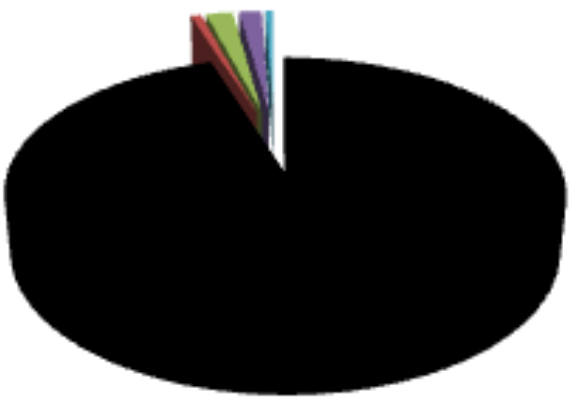

Winter 2011

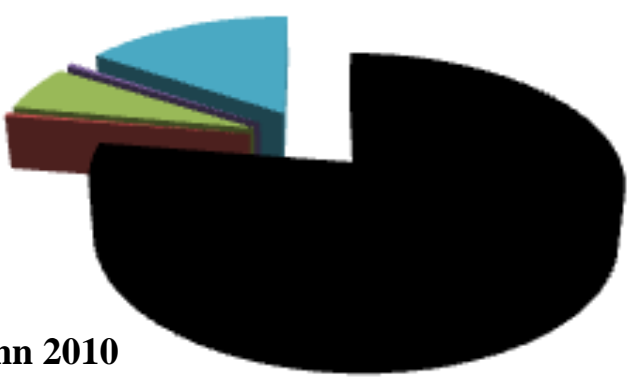

Autumn 2010

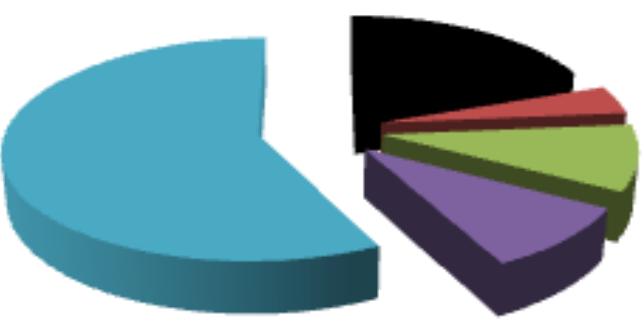

Summer 2011

Figure 4. Average Values of Seasonal Variations of nutrient salts at drains (2010-2011). 
for waste water and from 14.5 to 59.6 for sea water. Mahmoud et al. (2005) recorded average silicate content of $140.69 \mu \mathrm{M} / \mathrm{L}$ for El Mex bay water.

Dissolved inorganic nitrogen (DIN) and $\mathrm{PO}_{4}-\mathrm{P}$ are the main forms of $\mathrm{N}$ and $\mathrm{P}$ that are readily bioavailable for the growth of phytoplankton. The DIN/DIP ratio in the different regions of El-Mex Bay during study period is illustrated in Figure 5. The average ratios are higher at station 5 near El-Umoum drain in winter (108.38) and the lowest (2.53) was observed at station 1 in winter. In drains the higher values were observed as 380.63 in summer of drain 8 and the lower was 2.38 in the same season of drain 9. The average for the 4 seasons of $N / P$ ratios for whole area is 27.29. The higher ratios than that reported by Redfield's ratio with value of $16: 1$ revealed high nitrogen content in comparison with that of phosphorous. The values of N/P ratio could be related to allocthonous conditions (Whaby and Shriadah, 1984; Okbah, 2005). Smith (1979) found that phytoplankton yield depends mainly on N/P ratio; ratio $>15-17$ was indicating that phosphorus was the critical controlling factor, from $<9$ 10: 1 indicates that the yield varied with nitrogen and > 21 shows that phosphorus was the primary controlling factor.

\section{Water budget}

According to Abdallah (2007), the annual water budget flux into the Mediterranean sea at El-Mex Bay through ElMex pump station is $6.98 \times 106 \mathrm{~m}^{3} / \mathrm{d}$, El-Umum is $4.2 \times 10^{6} \mathrm{~m}^{3} / \mathrm{d}$, Al-Qalaa is $7.5 \times 10^{5} \mathrm{~m}^{3} / \mathrm{d}$, El-Nubaria is $1.54 \times 10^{6} \mathrm{~m}^{3} / \mathrm{d}$ and Mariut Lake $3.5 \times 10^{5} \mathrm{~m}^{3} / \mathrm{d}$. We can calculate from the present averages the annul salts budget (metric ton/year) reflux into the bay area as follows: for El-Umum drain: ammonia 284.39; nitrite 9.84; nitrate 26.84; phosphate 307.30 and silicate 112.86. For ElQalaa: ammonia 44.93; nitrite 0.34 ; nitrate 6.43 ; phosphate 120.35 and silicate 20.92. For El-Nubaria: ammonia 83.44; nitrite 6.28; nitrate 11.67; phosphate 117.10 and silicate 20.92. In Mariut Lake: ammonia 14.26; nitrite 0.13; nitrate 14.46; phosphate 28.25 and silicate 3.66 ton/ year.

Water quality standard limits of surface water parameters according to criteria produced by different local and international authorities and organizations are used to identify the water quality in El Mex bay area as shown in Table 4. The data declared that for many

parameters the values recorded in the present study are within the range of good quality except for ammonia, Chl$a$ and BOD which exceeded in some stations the recommended values by different authorities and organizations.

\section{Principal component analysis (PCA)}

It is applied for multivariate data derived from the water quality parameters analysis of 11 water samples for 4 seasons in El-Mex Bay and surrounded drains. The output data revealed that four factors (PC1- PC4) affected El-Mex water quality, association and sources, with cumulative covariance of $84.46 \%$. Varimax rotated components matrix is given in Table 5 to give an overview on the nature of loading among the parameters. PC1, PC2, PC3 and PC4 have covariance of 51.19, $13.89,10.73$ and $8.65 \%$ respectively. PC1 represented loading of salinity (0.947), transp. (0.812), Chl-c (0.744) and chlorinity (0.947) associated with negative loading to $\mathrm{NO}_{3}(-0.730)$. This factor refers to important role of salinity in the study area. This result is in accordance with those of Mahmoud et al. (2005), Zakaria et al. (2007) and Okbah et al. (2013). PC1may be affected by anthropogenic source of nitrate like fertilizers, industry, sewage and sludge. PC2 represented loading for temperature $(0.700)$, OOM (0.763), $\mathrm{NH}_{3}(0.893)$ and phos-phate (0.872). This factor indicated that at higher tem-perature, $\mathrm{OOM}, \mathrm{NH}_{3}$ and PO4 amount was higher. PC3 represented loading for DIN/DIP (0.800 associated with negative loading of Chl-b $\mu \mathrm{g} / \mathrm{L}(-0.708)$. PC4 represented high loading for BOD (0.972). Since, BOD is a measure of the oxygen used by microorganisms to decompose wastes it revealed a large quantity of organic waste in the study area.

\section{Extraction method}

This included principal component analysis; Rotation method: Varimax with Kaiser Normalization; marked loadings are $>0.70$; rotation converged in7 iterations; $\mathrm{N}=$ 11; Bold numbers positive loading, and italic number negative loading.

\section{Evaluation of water quality index (WQI)}

For the evaluation of hot spot stations, high values of principal component factor scores mean that this station is from hotspots. According to WQI, El-Dekhila Head and El Qalaa drain are two hot spots in this study area. According to PCA data the origins of pollution corresponding to the hot spots are summarized in Table 6.

\section{Conclusion}

The effect of wastewater on seawater was discussed through the water budges of nutrients from 4 drains into El Mex Bay. Based on the distribution of surface salinity in the investigated area, salinity gradient identified 4water types due to water circulation and high water currents. The residence time of El-Mex Bay water in the present study varied from 1.4 to 12.48 day. The present study throws light on the difference between the data of sea water and waste water compared to the previous studies. A noticeable variation in ammonia levels with striking 


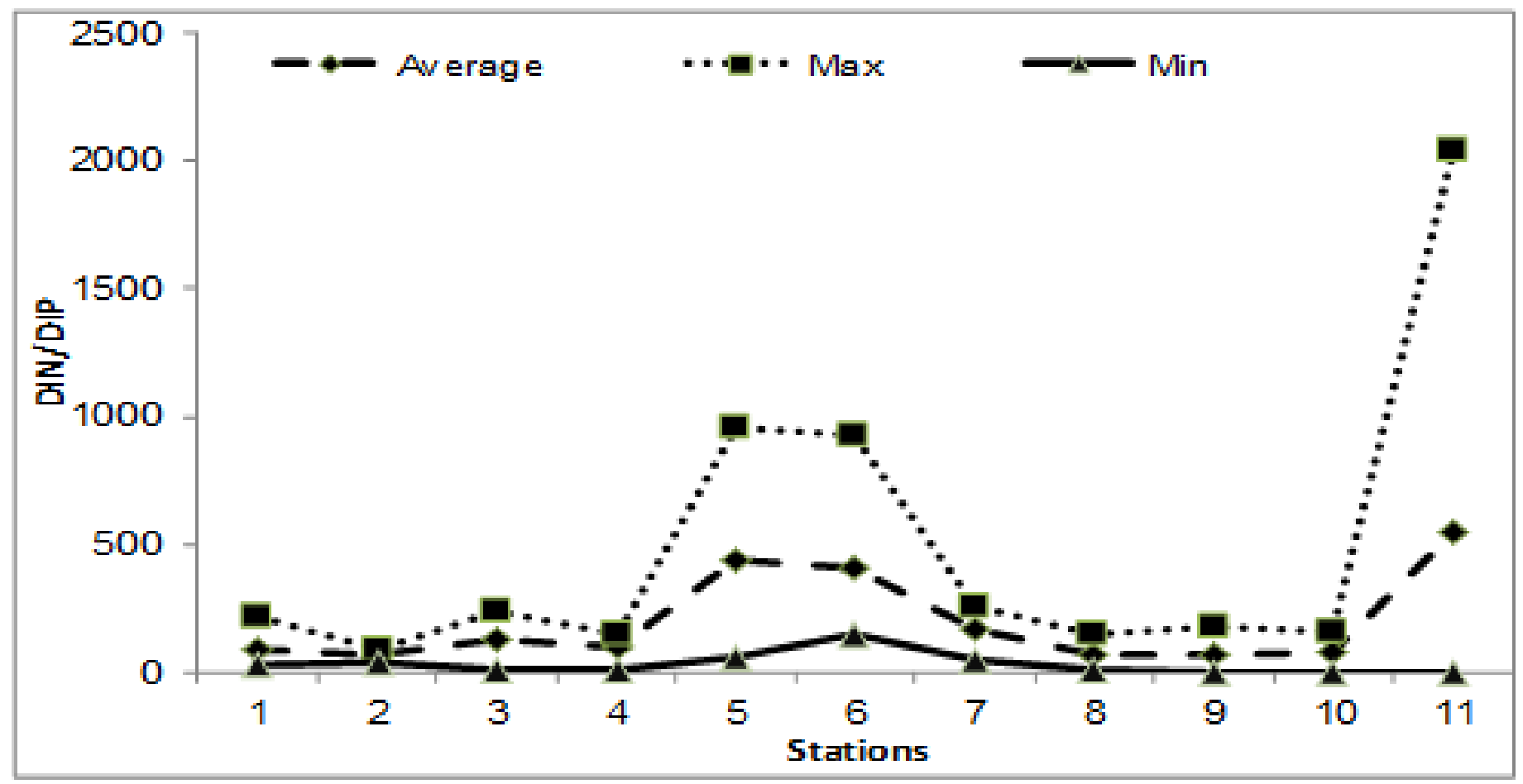

Figure 5. DIN/DIP distribution against sample stations.

Table 4. Water quality standard limits for surface water parameters according to criteria produced by different local and international authorities and organizations.

\begin{tabular}{|c|c|c|c|c|c|c|}
\hline \multirow[t]{2}{*}{ Parameter } & \multirow{2}{*}{$\begin{array}{l}\text { WHO } \\
1973\end{array}$} & \multirow{2}{*}{$\begin{array}{l}\text { EPA } \\
1982 \\
\end{array}$} & \multirow{2}{*}{$\begin{array}{c}\begin{array}{c}\text { Egyptian } \\
\text { Standards }\end{array} \\
1994\end{array}$} & \multirow[t]{2}{*}{$\begin{array}{c}\text { Portuguese Decree- } \\
\text { law no 263/98 } \\
\end{array}$} & \multicolumn{2}{|c|}{ Present study } \\
\hline & & & & & S.W & W.W \\
\hline Phosphate (mg/L) & 10 & - & 5 & 0.4 & $0.02-1.89$ & $0.01-1.8$ \\
\hline Nitrate $(\mathrm{mg} / \mathrm{L})$ & 0.05 & - & 40 & 25 & $0.01-1.57$ & $0.01-1.64$ \\
\hline Ammonia (mg/L) & 0.5 & - & 3 & 0.05 & $0.05-2.06$ & $0.07-39.42$ \\
\hline Chl-a $(\mu \mathrm{g} / \mathrm{L})$ & 20 & - & - & - & \multicolumn{2}{|c|}{ ND-241.91 } \\
\hline $\mathrm{DO}(\mathrm{mg} / \mathrm{L})(\mathrm{mg} / \mathrm{L})$ & 0.17 & 5 & $\geq 4$ & - & \multicolumn{2}{|c|}{ ND-22.26 } \\
\hline Transparency $(\mathrm{cm})$ & 10 & - & - & - & \multicolumn{2}{|c|}{$5-370 \mathrm{~cm}$} \\
\hline $\mathrm{pH}$ & $6-8.5$ & $6.5-9.00$ & $6.00-9.00$ & $6.5-8.5$ & \multicolumn{2}{|c|}{$7.36-8.97$} \\
\hline Temperature $\left({ }^{\circ} \mathrm{C}\right)$ & - & $16-32$ & $10>$ normal & - & \multicolumn{2}{|c|}{$15.0-30.9$} \\
\hline Salinity & - & - & 2 normal & - & $19.6-42.3$ & $0.3-7.3$ \\
\hline $\mathrm{BOD}(\mathrm{mg} / \mathrm{L})$ & - & - & $\leq 60$ & - & \multicolumn{2}{|c|}{$4.48-111.29$} \\
\hline $\mathrm{COD}(\mathrm{mg} / \mathrm{L})$ & - & - & 100 & - & \multicolumn{2}{|c|}{ NM } \\
\hline
\end{tabular}

increase at El Qalaa drain as a result of domestic sewage was due to the reduction of $\mathrm{NO}_{3}$ to $\mathrm{NH}_{4}-\mathrm{N}$ via a denitrifycation process. The large increase in nutrient loading has led to the impairment of many water bodies. This includes the eutrophication of water bodies that can lead to dissolved-oxygen depletion, species shifts, and fish kills. The high values of N/P ratio may be a result suggesting that phosphorus is the most limiting factor for the growth of phytoplankton. Principle component analysis (PCA) which was used to develop water quality index (WQI) revealed that El-Dekhila Head and El Qalaa drains were the most polluted sampling sites which resulted from the disposal of industrial, agricultural and domestic wastes. Ammonia, Chl-a and BOD according to different authorities and organizations exceed recommend values. Development of strategies for waste water treatment 
Table 5. Varimax rotated component matrix of physico chemical parameters and nutrient salts in El Mex Bay and surrounded drains.

\begin{tabular}{lcccc}
\hline Parameter & PC1 & PC2 & PC3 & PC4 \\
\hline Temperature $\left({ }^{\circ} \mathrm{C}\right)$ & -0.521 & 0.700 & -0.108 & 0.393 \\
Salinity & $\mathbf{0 . 9 4 7}$ & -0.284 & -0.063 & -0.099 \\
$\mathrm{pH}$ & 0.387 & -0.815 & 0.226 & 0.214 \\
Transparency $(\mathrm{cm})$ & $\mathbf{0 . 8 1 2}$ & -0.378 & 0.232 & 0.149 \\
$\mathrm{DO}(\mathrm{mg} / \mathrm{L})$ & 0.437 & -0.741 & 0.045 & 0.467 \\
$\mathrm{BOD}(\mathrm{ml} / \mathrm{L})$ & -0.057 & 0.080 & 0.089 & $\mathbf{0 . 9 7 2}$ \\
$\mathrm{OOM}(\mathrm{mgO} / \mathrm{L})$ & -0.416 & $\mathbf{0 . 7 6 3}$ & -0.015 & 0.409 \\
$\mathrm{Chl}-\mathrm{a}(\mu \mathrm{g} / \mathrm{L})$ & 0.482 & -0.237 & -0.024 & -0.113 \\
$\mathrm{Chl}-\mathrm{b}(\mu \mathrm{g} / \mathrm{L})$ & 0.301 & 0.008 & -0.709 & -0.258 \\
$\mathrm{Chl}-\mathrm{c}(\mu \mathrm{g} / \mathrm{L})$ & $\mathbf{0 . 7 4 4}$ & -0.150 & 0.456 & -0.013 \\
$\mathrm{NH}{ }_{3}(\mu \mathrm{M} / \mathrm{L})$ & -0.233 & $\mathbf{0 . 8 9 3}$ & 0.095 & 0.281 \\
$\mathrm{NO}{ }_{2}(\mu \mathrm{M} / \mathrm{L})$ & -0.298 & -0.353 & -0.673 & -0.268 \\
$\mathrm{NO}{ }_{3}(\mu \mathrm{M} / \mathrm{L})$ & -0.730 & 0.391 & 0.395 & -0.117 \\
$\mathrm{PO}(\mu \mathrm{M} / \mathrm{L})$ & -0.391 & $\mathbf{0 . 8 7 2}$ & 0.029 & -0.011 \\
$\mathrm{SiO} 4(\mu \mathrm{M} / \mathrm{L})$ & -0.745 & 0.482 & 0.235 & -0.038 \\
$\mathrm{DIN} / \mathrm{DIP}$ & 0.019 & -0.267 & $\mathbf{0 . 8 0 0}$ & -0.254 \\
$\mathrm{Chlorinity}$ & $\mathbf{0 . 9 4 7}$ & -0.284 & -0.063 & -0.099 \\
$\mathrm{Covariance} \%$ & 51.19 & 13.89 & 10.73 & 8.65 \\
$\mathrm{CV} \%$ & 51.19 & 65.08 & 75.81 & 84.46 \\
\hline
\end{tabular}

Table 6. Principal component factor scores and water quality index (WQI) of water samples in study area.

\begin{tabular}{lcccccl}
\hline Hot spot & PC1 & PC2 & PC3 & PC4 & WQI & Parameter \\
\hline El-Dekhila Head (St.1) & 0.63 & -0.688 & -0.265 & 2.36 & 0.477 & $\begin{array}{l}\text { According to high value of PC4 the effective } \\
\text { parameter is BOD (41.59 mg/L) }\end{array}$ \\
El Qalaa drain & -0.532 & $\mathbf{2 . 7 4}$ & 0.27 & 0.88 & $0.253 \begin{array}{l}\text { According to high value of PC2 the effective } \\
\text { parameters are } \mathrm{Temp}\left(25.73^{\circ} \mathrm{C}\right), \mathrm{OOMM}^{(54.75} \\
\mathrm{mgO} / \mathrm{L}), \mathrm{NH}_{3}(1351.88 \mu \mathrm{M} / \mathrm{L}) \mathrm{and} \mathrm{PO} \mathrm{O}_{4}(20.91 \mu \mathrm{M} / \mathrm{L})\end{array}$ \\
\hline
\end{tabular}

$\mathrm{PC}=$ principal component factor score; WQI=Water Quality Index; Bold number indicates high effect of factor scores $(>0.7)$.

must be evaluated. Alternatively, environmentally acceptable, biocide should be strongly supported.

\section{Conflict of Interests}

The author(s) have not declared any conflict of interests.

\section{REFERENCES}

Abdallah MAM (2007). Speciation of Trace metals in coastal sediments of El-Max bay south of Mediterranean sea-west of Alexandria (Egypt). Environ. Monit. Assess.132:111-23.

Abdallah MA (2008). Trace metal behavior in Mediterranean-Climate Coastal Bay: El-Mex Bay, Egypt and its Coastal Environment. Glob. J. Environ. Res. 2(1):23-29.

Abdel Ghani SA, Shobier AH, Shreadah MA (2013). Assessment of Arsenic and Vanadium Pollution in Surface Sediments of the Egyptian Mediterranean Coast. J. Environ. Technol. Manag. 16 (1/2): 82-101.

Carlson R (1977). A trophic state index for lakes. Limnol. Oceanogr. 22 (2):361-369

Carritt DE, Carpenter JH (1966). Comparison and evaluation of currently employed modifications of Winkler method for determining dissolved oxygen in seawater. ANASCO Report. J. Mar. Res. 24(3): 286-318.

Chester R (2000). Marine Geochemistry, 2nd ed. Block Well Science Ltd $493 \mathrm{pp}$.

Cloern JE (2001). Our evolving conceptual model of the coastal eutrophication problem. Mar. Ecol. Prog. Ser. 210: 223-253.

Cole GA (1979). Text Book of Limnology. 2nd eds. C.V. Mosby Company, $426 \mathrm{pp}$.

Davis JC (1986). Statistics and Data Analysis in Geology. John Wiley \& Sons. Inc., New York.

Duursma EK (1961). Dissolved organic Carbon, Nitrogen and Phosphorus In the Sea NeTherl. J. Sea Res. 1(1-2):1-141.

EEAA (2009). A scientific report of Alexanderia integrated coastal zone management project. Environmental and social impact Assessment 113pp.

El Gindy AA, Aboul-Dahab O, Halim Y (1986). Pleiminary estimates of water and trace metals balances in El Mex bay, west of Alexandria, Egypt. Rapp. Commm. Int. Mer Medit. 30(2): 127.

Emara HI, Shriadah MA, Maoustafa Th H, El- Deek MS (1992). Effects of Sewage and Industrial Wastes on the Chemical Characterstics of the Eastern harbor and El- Max Bay Waters of Alexandria, Egypt. Sci. Total Environ. P: 773-784

Emara HI, Shriadah MA, Maoustafa Th. H, El- Deek MS (1995). Trace metals-nutrient salts relationship in coastal sea-water of Alexandria. Procedings of the Second International Conference on the 
Mediterranean Coastal Environment, MEDCOAST 95, October 2427, 1995; Tarragona Spain, E. Ozhan (Editor)

Environmental Control and Public Health (ECPH) (1975). Water analysis standard and treatment. Eyro. \& spottiswood Ltd. 131p.

El Zokm GM, SE El-Gohary, Abd-El-khalek DE (2012). Studies of Some Heavy Metals in Water and Sediment in El-Max Fish Farm, Egypt. World Appl. Sci. J. 18(2):171-180.

Fahmy MA, Tayel FT, Shriadah MA (1997). Spatial and seasonal variations of dissolved trace metals in two contaminated basins of the coastal Mediterranean Sea Alexandria, Egypt. Bull. Fac. Sci. Alex. Univ. 37(2):18-29.

FAO (Food and Agriculture Organization of the United Nations) (1975). Permanganate values of organic matter in natural waters. Fisheries Technical 137:169-171.

Faragallah HM, Askar Al, Okbah MA, Moustafa HM (2009). Physicochemical characteristics of the open Mediterranean sea water far about $60 \mathrm{Km}$ from Damietta harbor, Egypt. J. Ecol. Nat. Environ. 1(5):106-119.

Fathy S, Abdel Hamid F, Shreadah M, Mohamed L, El-Gazar M (2012). Application of Principal Component Analysis for Developing Water Quality Index for Selected Coastal Areas of Alexandria Egypt. Recourses Environ. J. 2 (6):297-305.

Hamdy R, Dorgham MM, El-Rashidy HH, Atta MM (2014). Biometry and reproductive biology of Pseudonereis anomala Gravier 1901 (Polychaeta: Nereididae) on the Alexandria coast, Egypt. Oceanologia 56 (1):41-58.

Hutchinson GE (1957). A Treatise on L imnology (Geography, Physics and Chemistry). John Wiley and Sons. Inc., New York.

Lohani B, Todino G (1984). Water Quality Index of Chao Phraya River. J. Environ. Eng. 110 (6):1163-1176.

Mahmoud Th. H, Masoud MS, Shaltout NA (2005). Physicochemical characteristics of different water types in El-Mex Bay, Alexandria -Egypt, proceeding of MARINE MTF -IEEE, ocean ,19-23 September conference, Washington DC, USA .

McCave IN (1989). Eberhard, University of Cambridge 1-38.

Nessim RB, Bassiouny AR, Zaki HR, Moawad MN, Kandeel KM (2010). Environmental studies at El-Mex Region (Alexanderia-Egypt) During 2007-2008. World Appl. Sci. J. 9(7): 779-787.

Okbah MA, Ibrahim AMA, Gamal MNM (2013). Environmental monitoring of linear alkylbenzene sulfonates and physicochemical characteristics of seawater in El-Mex Bay (Alexandria, Egypt). Environ. Monit. Assess. 185:3103-3115

Okbah,M.A.(2005): Nitrogen and Phosphorus Species of Lake Burullus Water (Egypt), Pub. in: Egyptian J. of Aquatic Research, 31(1), p. 186-198.

Olobaniyi S, Owoyemi F (2006). Characterization by Factor Analysis of the Chemical Facies of Groundwater in the Deltaic Plain Sands Aquifer of Warri, Western Niger Delta, Nigeria. Afr. J. Sci. Technol. 7(1):73-81.

Riley JP, Chester CH (1971). Introduction of marine chemistry, Academic press, London- New York, 465p.

Said MA, El-Deek MS, Mahmoud Th. H, Shriadah MA (1994). Effect of pollution on the hydrochemical characteristics of different water types in El-Mex Bay area, west of Alexandria, Egypt. Acta Adriatica 34 $(1 / 2): 9-19$

Shaltout NA (2008). Inorganic Carbon Cycle of Alexandria Coastal Water, Ph.D. Thesis, Chemistry Department, Faculty of Science, Alexandria University, Egypt, 257p.

Shams-El-Din N.G, Dorgham M.M. (2007). Phtoplankton community in Abu-Qir Bay as a Hot spot on the southeastern Mediterranean Coast. Egyptian Journal of Aquatic research.Vol.33.No.1:163-182.
Shobier AH, Abdel Ghani SA, Shreadah MA (2011). Distribution of Total Mercury in Sediments of Four Semi-Enclosed Basins along the Mediterranean Coast of Alexandria. Egypt. J. Aquat. Res. 37(1):1-11.

Shriadah MA, Emara I (1992a).Iron, Manganes, Nickel, Lead and Cadmium in fish and crustacean from the Eastern Harbour and ElMex Bay of Alexandria. Bulletin High Institutes 3:515-525.

Shriadah MA, Emara I (1992b). Major cations and alkalinity in the Eastern harbor and El-MexBey. Bull. Fac. Sci. Alex. Univ. 32(A): 156174.

Shreadah MA, Abdel Moneim MI, Said TO, Fathallah EMI, Mahmoud ME (2013). PAHs in Seawater of the Semi-Closed Areas along the Alexandria Coast of Egyptian Mediterranean Sea. J. Environ. Prot. 4: 1307-1317.

Shriadah MA, Emara HI (1996). Heavy metals (Iron, manganese, nickel, Cadmium, and Lead) in the sediments from the Eastern harbor and El-Mex Bay of Alexandria, Egypt. Proc. 6th Int. Symp. Environ. Prot. Is a must, 916- 927, Alexandria,21-23 May, Egypt.

Shriadah MA, Said TO, Younis AM, Farag RS (2006a). Physicochemical characteristics of the semi-closed areas along the Mediterranean Coast of Alexandria, Egypt. Egypt. J. Aquat. Res. 32: 38-48.

Shriadah MA, Said TO, Younis AM, Farag RS (2006b). Speciation of Organotin Compounds in Sediments of semi- closed areas along the Mediterranean Coast of Alexandria. Chem. Ecol. 22 (5): 395-404.

Shreadah, M. A., Said T. O., Abdel Moniem M. I., Fathallah E. I., and Mahmoud M. E. (2011). PAHsin Sediments along the Semi-closed Areas of Alexandria, Egypt. Journal of Environmental Protection, Vol. 2(6), P: 700-709.

Shreadah MA, Said TO, Abdel Moniem MI, Fathallah El, Mahmoud ME

(2012). Polychlorinated biphenyls and chlorinated pesticides in Sediments along the Semi-closed Areas of Alexandria, Egypt. J. Environ. Prot. 3(2):141- 149.

Sillen LG (1961). The physical Chemistry of Seawater. Publ. Amer. Ass. Adv. Sci. 67 Lectures in The International Oceanographic Congress in New York, 549-581.

Stanley JD, Jorstad TF, Gooddio F (2006). Human impact on sediment mass movement and submergence of ancient sites in the two harbours of Alexandria, Egypt. Norwegian J. Geol. 86:337-350.

Strickland HD, Parsons TR (1972). A practical handbook of seawater analysis Fish Res. Bd.CAnda Bull., 157, 2nd ed., pp. 310.

Tayel FTR, Fahamy MA, Shriadah MMA (1996). Studies on the physico-chemical characteristics of Max Bay and New Dekhalila Harbor waters of Alexandria, Egypt. Bull. Nat. Inst. Oceanogr. Fish., A.R.E., 22:1-18.

Wahby SD, Shreadah MA (1984). The effect of sewage discharge on some chemical characteristics of seawater. VII Journees Etud Pollutions, Lvcerene. CIESM, P: 81-90.

WHO (1973). Health Hazards of The Human Environment, Geneva, Switzerland

UNEP (Athena) (1988). pp. 23-27.

UNESCO, FAO, UNEP (1988). Eutrophication in the Mediterranean sea MAP.Technical report series NO 106 UNEP Athens

Zakaria HY, Radwan AA, Said MA (2007). Influence of salinity variations on zooplankton community in El-Mex Bay, Alexandria. Egypt. J. Aquat. Res. 33(3):52-67. 